Artikel Penelitian

\title{
Analisis Sidik Jari Kromatografi Lapis Tipis Anting-Anting (Acalypha indica L.)
}

\author{
Muhammad Teguh Laksono, Elok Kamilah Hayati*
}

Program Studi Kimia, Fakultas Sains dan Teknologi, Universitas Islam Negeri Maulana Malik Ibrahim, Malang, Indonesia, 65144

INFO ARTIKEL

Sejarah Artikel

Diterima 2 April 2021

Direvisi 19 Agustus 2021

Tersedia online 9 Desember 2021

*Penulis korespondensi:
eloksunardji@yahoo.com

\section{ABSTRAK}

Anting-anting plant (Acalypha indica L.) is a plant that the community has used as raw material for herbal medicine. Anting-anting plants contain chemical compounds, so it is difficult to ensure these plants' safety and quality control. The research objective was to validate the method by knowing the stability, specificity, precision, and rigidity of the chromatographic profile of alkaloid compounds in the TLC analysis of the anting-anting extract. Extraction was carried out using ethyl acetate solvent for 20 minutes with a frequency of $42 \mathrm{kHz}$. The eluent used is cyclohexane: toluene: diethylamine $(75: 15: 10)$ with Dragendorff reagent. The method of validation was acceptable according to the criteria except for the stability test of the analyte during chromatography. The instability of the analyte is indicated that not all spots form a straight diagonal line. The specificity of the method was carried out by comparing the fingerprint patterns of the leaves of the anting-anting with ekor kucing (Acalypha hibsida Farm.) and teh-tehan plants (Acalypha siamensis). The fingerprint profile showed a yellow stain $(\mathrm{Rf}=0.39)$ on the leaves of the anting-anting, which did not appear in the fingerprint profiles of the two comparison samples.

Keywords: anting-anting, fingerprint analysis, thin layer chromatography, method validation

Anting-anting (Acalypha indica L.) merupakan tanaman yang telah dimanfaatkan masyarakat sebagai bahan baku obat herbal. Anting-anting mengandung banyak senyawa kimia sehingga sulit menjamin keamanan dan pengendalian mutu dari tanaman tersebut. Penelitian ini dilakukan untuk validasi metode dengan mengetahui kestabilan, spesifitas, presisi, dan ketegaran profil kromatografi senyawa alkaloid pada analisis KLT ekstrak anting-anting. Ekstraksi dilakukan menggunakan pelarut etil asetat selama 20 menit dengan frekuensi $42 \mathrm{kHz}$. Eluen yang digunakan adalah sikloheksana : toluena : dietilamin (75:15:10) dengan reagen Dragendorff. Validasi metode dapat diterima sesuai kriteria kecuali uji stabilitas analit selama kromatografi. Ketidakstabilan analit ditunjukkan dengan seluruh noda yang dihasilkan tidak membentuk garis diagonal yang lurus. Spesifitas pada metode dilakukan dengan membandingkan pola sidik jari daun anting-anting dengan daun ekor kucing (Acalypha hibsida Farm) dan daun tehtehan (Acalypha siamensis). Profil sidik jari menunjukkan bahwa terdapat noda berwarna kuning kehijauan $(R f=0,39)$ pada daun anting-anting yang tidak muncul pada profil sidik jari kedua sampel pembanding tersebut.

Kata kunci: anting-anting, analisis sidik jari, kromatografi lapis tipis, validasi metode 


\section{Pendahuluan}

Indonesia merupakan salah satu negara tropis yang kaya akan keanekaragaman jenis tumbuhan dan banyak dimanfaatkan sebagai bahan baku obat herbal [1]. Saat ini obat herbal banyak digunakan sebagai pengobatan alternatif karena ketersediaannya yang melimpah di alam, harga terjangkau, dan tidak menimbulkan efek samping [2]. Anting-anting (Acalypha indica L.) merupakan salah satu tanaman yang termasuk dalam genus Acalypha dengan ciri daun berbentuk belah ketupat, daun tunggal, berwarna hijau, berujung runcing, dan tepi bergerigi [3]. Tanaman ini telah dimanfaatkan oleh masyarakat sebagai obat herbal dengan berbagai khasiat diantaranya, obat disentri, diare, gangguan pencernaan, muntah darah, mimisan [4], antibakteri [5, 6], antioksidan [7], antidiabetes [8], dan menurunkan kadar gula darah [9]. Anting-anting secara empiris juga dapat digunakan sebagai pengobatan antimalaria [8]. Alkaloid yang terkandung dari ekstrak etil asetat daun anting-anting secara in vivo diketahui dapat menghambat pertumbuhan parasit dengan cara menghalangi pertumbuhan parasit melalui intraseluler kolin [10].

Anting-anting mengandung senyawa flavonoid, triterpenoid, saponin, senyawa fenolik, steroid, tanin, minyak atsiri, asam askorbat, $\beta$-sitosterol, kuersetin, dan kaemfero [10, 11, 12, 13]. Kualitas dan keaslian tanaman obat dapat dievaluasi berdasarkan senyawa penciri yang terkandung didalamnya. Kehadiran senyawa-senyawa penciri tidak selalu menjamin bahwa produk tersebut mengandung satu jenis tanaman obat tanpa adanya campuran tanaman lain yang mempunyai kemiripan fisiknya. Oleh karena itu, perlu dikembangkan suatu metode kendali mutu untuk tanaman obat.

Banyaknya kandungan senyawa kimia dalam suatu tanaman obat dapat menjadi faktor kesulitan dalam menjamin pengendalian mutu dari tanaman tersebut. Hal tersebut dapat memungkinkan terjadinya pemalsuan obat apabila terjadi penurunan pasokan bahan baku suatu tanaman obat. Pemalsuan obat herbal biasanya dilakukan dengan mencampurkan dengan tanaman yang memiliki morfologi sama atau berkerabat dekat. Oleh sebab itu, perlu adanya metode pengendalian mutu yang dapat menunjukkan ciri spesifik dari suatu tanaman obat, sehingga mampu menghasilkan suatu produk yang bermutu terkait konsistensi kualitas, khasiat, dan keamanannya [14].

Analisis sidik jari merupakan salah satu metode yang digunakan untuk menampilkan senyawa aktif yang dikandung oleh suatu tanaman obat dalam bentuk kromatogram sidik jari, sehingga karakteristik tanaman obat tersebut dapat digambarkan secara menyeluruh [15]. Metode ini dimanfaatkan untuk kontrol kualitas senyawa multikomponen dalam suatu tumbuhan obat karena profil kromatografi yang dihasilkan dapat menggambarkan komposisi sampel dan stabilitasnya [16]. Metode analisis sidik jari pada penelitian ini menggunakan kromatografi lapis tipis (KLT) karena waktu yang dibutuhkan lebih singkat, sampel dan fase gerak yang digunakan lebih sedikit, serta lebih sensitif dan selektif [17]. Analisis sidik jari kromatografi lapit tipis (KLT) dapat memberikan data fundamental yang mengindikasikan stabilitas dan konsistensi produk obat herbal [18]. Penelitian ini bertujuan mengembangkan metode analisis sidik jari anting-anting menggunakan KLT hasil ekstraksi ultrasonik dengan validasi metode meliputi stabilitas analit, spesifitas, presisi, presisi antara, dan ketegaran.

\section{Bahan dan Metode}

\subsection{Bahan}

Adapun bahan-bahan yang digunakan pada penelitian ini adalah daun anting-anting (Acalypha indica L.), daun ekor kucing (Acalypha hibsida Farm.), dan daun teh-tehan (Acalypha siamensis) yang berasal dari pesisir pantai di Kabupaten Malang. Bahan kimia lain yang juga diperlukan adalah standar berberin 100 ppm, etil asetat p.a (Merck), sikloheksana p.a (Merck), toluena, dietilamin, reagen Dragendorff, dan pelat KLT silika gel $60 \mathrm{~F}_{254}$ (Merck, Darmsatd, Jerman).

\subsection{Preparasi Sampel}

Bagian anting-anting (Acalypha indica L.) yang digunakan adalah daunnya. Daun dicuci bersih, dipotong kecil-kecil dan dikeringaningkan. Simplisia yang telah kering dihaluskan dan dilakukan pengayakan dengan ukuran 90 mesh.

\subsection{Ekstraksi Anting-Anting}

Simplisia daun anting-anting ditimbang sebanyak $1 \mathrm{~g}$ dan diekstraksi dengan $10 \mathrm{~mL}$ etil asetat. Kemudian disonikasi pada frekuensi $42 \mathrm{kHz}$ selama 20 menit pada suhu ruang. Hasil ekstraksi disaring dan diambil ekstrak kasarnya [19].

\subsection{Uji Stabilitas Analit pada Pelat dan Dalam Larutan}

Ekstrak sebanyak $15 \mu \mathrm{L}$ diaplikasikan sebanyak 4 lajur pada pelat KLT 5x10 cm. Ekstrak segar daun anting-anting diaplikasikan pada lajur 1. Lalu ekstrak tersebut disimpan dan pelat didiamkan selama 90 menit. Ekstrak yang telah disimpan selama 90 menit sebelumnya diaplikasikan pada lajur 3. Disiapkan pula ekstrak segar daun anting-anting yang akan diaplikasikan pada lajur 2 dan 4 segera sebelum dielusi. Kemudian, pelat dikembangkan menggunakan bejana twin trough dan didokumentasikan sebelum dan setelah derivatisasi. Ekstrak dapat dikatakan stabil 90 menit pada pelat dan 90 menit dalam larutan sebelum proses kromatografi jika perbedaan nilai $R f \leq 0,05$ [20]. 


\subsection{Uji Stabilitas Analit selama Kromatografi}

Ekstrak diaplikasikan sebanyak $15 \mu \mathrm{L}$ sebagai noda pada sudut kiri bawah pelat KLT berukuran $10 \times 10 \mathrm{~cm}(10 \mathrm{~mm}$ dari masing-masing tepi). Pelat dielusi dalam bejana twin trough hingga fase gerak mencapai tinggi $8 \mathrm{~cm}$ dari posisi aplikasi ekstrak. Setelah proses elusi, pelat diangkat dan dikeringanginkan. Kemudian, pelat diputar $90^{\circ}$ ke kanan dan dielusi menggunakan eluen yang baru hingga mencapai tinggi $8 \mathrm{~cm}$. Pelat disemprot menggunakan pereaksi Dragendorff dan didokumentasi. Ekstrak dikatakan stabil jika noda atau pola membentuk posisi diagonal lurus yang menghubungkan posisi awal ekstrak dan ditotolkan dengan titik perpotongan garis dari dua sisi pelarut [20].

\subsection{Uji Stabilitas Visualisasi}

Ekstrak daun anting-anting diaplikasikan sebanyak $15 \mu \mathrm{L}$ pada pelat $\mathrm{KLT} 2 \times 10 \mathrm{~cm}$, kemudian pelat dikembangkan menggunakan bejana twin trough. Selanjutnya pelat diderivatisasi dan diamati di bawah lampu UV $366 \mathrm{~nm}$. Pengamatan dilakukan pada menit ke-5, 10, 20, 30, dan 60 . Hasil yang diperoleh dikatakan stabil jika tidak terjadi perubahan yang signifikan pada noda selama 60 menit [20].

\subsection{Uji Spesifitas}

Ekstrak daun anting-anting, ekstrak daun ekor kucing, dan ekstrak daun teh-tehan masing-masing diaplikasikan sebanyak $15 \mu \mathrm{L}$ pada lajur 1, 2, dan 3 pada pelat KLT 4x10 cm. Pelat dielusi menggunakan bejana twin trough. Pelat didokumentasikan sebelum dan setelah derivatisasi, kemudian hasil kromatogram dibandingkan [20].

\subsection{Uji Presisi}

Sampel daun anting-anting diekstraksi dengan ekstraksi ultrasonik sebanyak 3 kali. Masing-masing ekstrak diaplikasikan sebanyak $15 \mu \mathrm{L}$ pada pelat KLT $10 \times 10 \mathrm{~cm}$ (setiap 1 ekstrak diaplikasikan pada 3 lajur dalam 1 pelat). Pengaplikasian ekstrak dilakukan pada tiga pelat yang berbeda. Pengembangan setiap pelat dilakukan pada chamber dengan menggunakan fase gerak yang baru disiapkan hingga proses elusi mencapai tinggi $8 \mathrm{~cm}$. Pelat didokumentasi sebelum dan setelah disemprot menggunakan pereaksi Dragendorff. Nilai $R f$ pada masing-masing zona noda dihitung dan ditentukan rerata serta simpangan relatifnya. Hasil dapat diterima jika pola sidik jari identik terkait dengan jumlah, letak, warna, intensitas noda, dan memiliki perbedaan nilai $R f \leq 0,02$ [20].

\subsection{Uji Presisi Antara}

Pengaplikasian ekstrak dilakukan pada 2 hari yang berbeda setelah dilakukannya pengujian presisi. Pada hari kedua dan ketiga disiapkan pelat KLT dan diaplikasikan sebanyak 3 kali ulangan (satu pelat per hari). Masing-masing ekstrak kasar diaplikasikan sebanyak $15 \mu \mathrm{L}$ pada pelat KLT 10x10 cm (setiap 1 ekstrak diaplikasikan pada 1 lajur). Kemudian pengembangan setiap pelat dilakukan di bejana pengembang hingga mencapai tinggi $8 \mathrm{~cm}$. Pelat didokumentasi sebelum dan setelah disemprot menggunakan pereaksi Dragendorff. Nilai $R f$ pada masing-masing zona noda dihitung kemudian ditentukan rerata dan simpangan relatifnya. Hasil dapat diterima jika pola sidik jari identik terkait jumlah, letak, warna, intensitas warna, dan perbedaan nilai $R f \leq 0,05$ [20].

\subsection{Uji Ketegaran terhadap Bejana Pengembang}

Ekstrak diaplikasikan pada pelat KLT 4x10 cm. Ekstrak diaplikasikan pada lajur 1 dan 2 sebanyak $15 \mu \mathrm{L}$, sedangkan standar berberin 100 ppm pada lajur 3 sebanyak 1 totol. Pelat dikembangkan dalam bejana twin trough dan flat bottom. Pelat didokumentasi sebelum dan setelah disemprot menggunakan pereaksi Dragendorff. Kemudian, dibandingkan hasil pengelusian menggunakan bejana twin trough dan flat bottom. Hasil dapat diterima jika pola sidik jari identik terkait dengan jumlah, letak, warna, intensitas warna noda, dan perbedaan nilai $R f \leq 0,05$ [20].

\subsection{Uji Ketegaran terhadap Jarak Pengembangan}

Ekstrak diaplikasikan pada pelat KLT 4x10 cm. Ekstrak diaplikasikan pada lajur 1 dan 2 sebanyak $15 \mu \mathrm{L}$, sedangkan standar berberin pada lajur 3 sebanyak 1 totol. Pelat dikembangkan dalam bejana twin trough hingga fase gerak mencapai tinggi $7 \mathrm{~cm}$ dari tanda titik awal penotolan. Pelat didokumentasi sebelum dan setelah disemprot menggunakan pereaksi Dragendorff. Kemudian, pelat hasil pengujian jarak pengembangan $7 \mathrm{~cm}$ dan $8 \mathrm{~cm}$ dibandingkan. Hasil dapat diterima jika pola sidik jari identik terkait dengan jumlah, letak, warna, intensitas warna, dan perbedaan nilai $R f \leq 0,05$ [20].

\section{Hasil dan Pembahasan}

\subsection{Preparasi Sampel}

Sampel dicuci untuk menghilangkan pengotor yang dapat mengganggu proses ekstraksi. Kemudian sampel dikeringanginkan karena alkaloid memiliki sifat fisik yang kurang tahan terhadap panas [19]. Pengeringan berfungsi untuk 
menurunkan kadar air, mencegah tumbuhnya jamur, dan menghilangkan reaksi enzimatis, sehingga sampel dapat disimpan lebih lama. Sampel yang telah kering dihaluskan dengan ayakan 90 mesh dan diperoleh serbuk halus. Ukuran partikel yang semakin kecil akan memperluas permukaan sampel sehingga dapat memperbesar interaksi antara partikel serbuk dengan pelarut dan menyebabkan pelarut lebih mudah memecah dinding sel sampel.

\subsection{Ekstraksi Ultrasonik Daun Anting-Anting (Acalypha indica L.)}

Ekstraksi daun anting-anting dilakukan menggunakan pelarut etil asetat secara ultrasonik dengan waktu optimum 20 menit. Hal tersebut dikarenakan pelarut tersebut memiliki sifat semipolar, sehingga dapat melarutkan senyawa semipolar yang terdapat di dalam sel, salah satunya adalah alkaloid. Perbandingan antara sampel dan pelarut yang digunakan adalah 1:10 (b/v) karena dapat menghasilkan pola pemisahan alkaloid yang jelas pada anting-anting [21, 22]. Hasil ekstraksi daun anting-anting diperoleh ekstrak berwarna hijau kehitaman (Gambar 1).

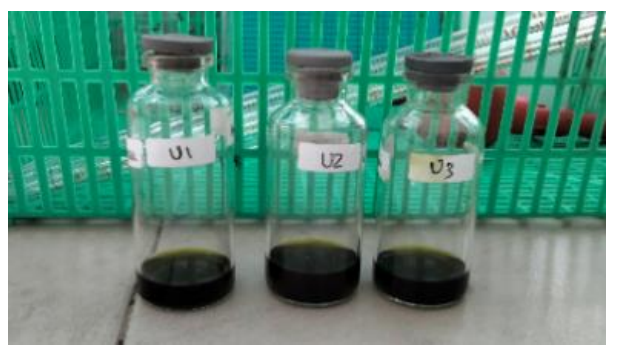

Gambar 1. Filtrat ekstrak daun anting-anting (Acalypha indica L.).

\subsection{Stabilitas Analit}

Uji stabilitas pada daun anting-anting bertujuan untuk mengetahui mutu bahan baku maupun produk tanaman tersebut baik selama masa penyimpanan maupun pengujian. Stabilitas analit sebelum dan setelah proses elusi maupun setelah derivatisasi perlu diketahui karena selama proses preparasi, elusi, hingga derivatisasi dan deteksi UV dilakukan secara terpisah yang dapat memengaruhi sistem kerja kromatografi. Keberadaan sampel pada permukaan pelat KLT berupa ekstrak dapat terpengaruh oleh cahaya, udara, debu, suhu, dan faktor-faktor lainnya yang dapat mengubah sampel.

\subsubsection{Stabilitas Analit pada Pelat dan Dalam Larutan}

Stabilitas analit pada pelat dan dalam larutan (sebelum kromatografi) dapat diketahui dengan mengembangkan dua ekstrak yang disiapkan pada waktu berbeda. Lajur 1 dan 2 bertujuan untuk mengevaluasi stabilitas analit pada pelat, sedangkan lajur 3 dan 4 untuk mengevaluasi stabilitas analit dalam larutan. Hasil penelitian menunjukkan bahwa keempat lajur menghasilkan pola yang relatif sama (Gambar 2). Tidak ada perbedaan jumlah, warna, dan intensitas noda pada kromatogram yang dihasilkan. Analit dikatakan stabil pada pelat dan dalam larut apabila perbedaan nilai $R f$ yang diperoleh $\leq 0,05$ [20]. Hal tersebut mengindikasikan bahwa analit tetap stabil meskipun didiamkan pada pelat dan dalam larutan selama 90 menit sebelum kromatografi dimulai.

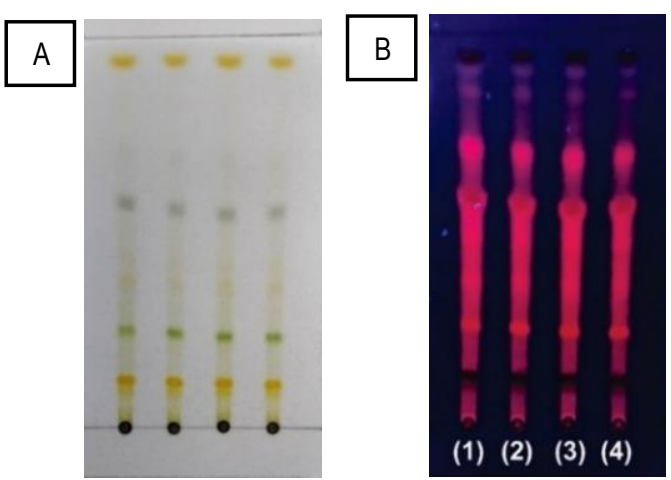

Gambar 2. Stabilitas analit daun anting-anting selama 90 menit pada pelat dan dalam larutan. Lajur (1), sampel 90 menit sebelum kromatografi, Lajur (2) dan (4), sampel segar sebelum kromatografi, lajur (3) sampel 90 menit sebelum aplikasi pada pelat. (A) pelat KLT tanpa penyinaran lampu UV dan (B) pelat KLT di bawah lampu UV $256 \mathrm{~nm}$.

\subsubsection{Stabilitas Visualisasi}

Uji stabilitas visualisasi perlu dilakukan karena adanya waktu jeda dalam penyelesaian kromatografi dan deteksi komponen. Uji tersebut dilakukan untuk mengetahui ketahanan pola dan intensitas warna pada pelat yang telah 
diderivatisasi menggunakan reagen Dragendorff selama 60 menit. Hasil pengamatan menunjukkan bahwa tidak ada perubahan pada jumlah noda maupun intensitas warna pada pelat, sehingga hal tersebut mengindikasikan bahwa profil sidik jari daun anting-anting setelah derivatisasi dengan reagen Dragendorff secara penampakan visual tidak terjadi perubahan yang signifikan selama 60 menit pengamatan (Gambar 3).

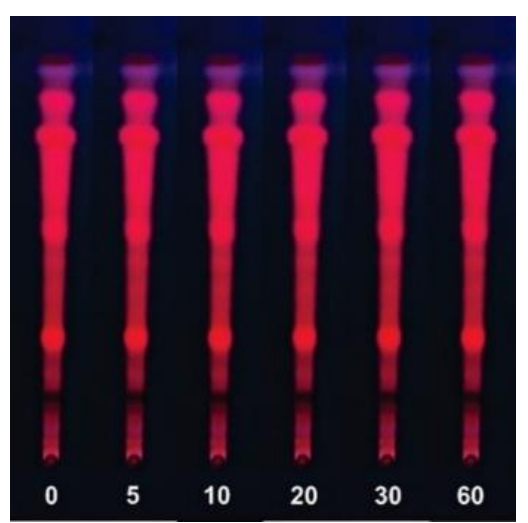

Gambar 3. Stabilitas visualisasi daun anting-anting setelah derivatisasi dengan reagen Dragendorff.

\subsection{Uji Spesifitas}

Uji spesifitas anting-anting dilakukan dengan membandingkan tanaman yang berkerabat dekat dan mempunyai morfologi yang sama dengan anting-anting. Pada penelitian ini uji spesifitas dilakukan dengan menggunakan tanaman ekor kucing dan tanaman teh-tehan sebagai pembanding (Gambar 4). Suatu metode kualitatif dikatakan spesifik jika pengujian terhadap dua sampel uji atau lebih dengan identitas yang sama memberikan hasil yang sama, dan begitupun sebaliknya.
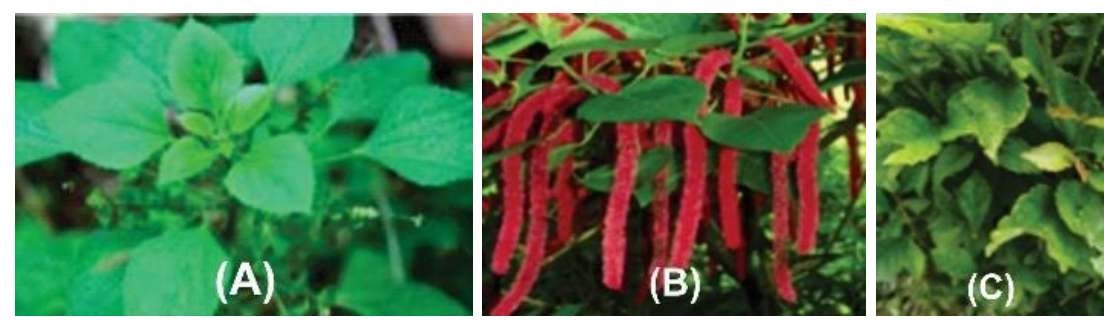

Gambar 4. Morfologi (A) daun anting-anting, (B) daun ekor kucing, dan (C) daun teh-tehan.
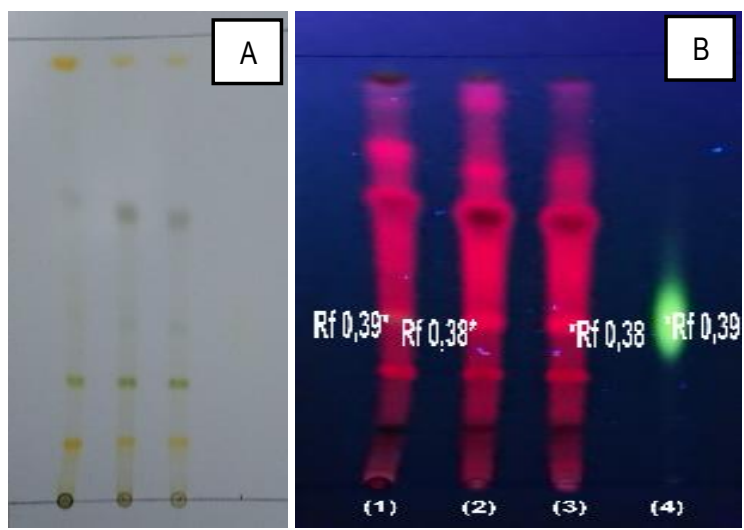

Gambar 5. Hasil uji spesifitas (1) daun anting-anting, (2) daun ekor kucing, (3) daun teh-tehan, dan (4) standar berberin 100 ppm. (A) pelat KLT tanpa penyinaran lampu UV dan (B) pelat KLT di bawah lampu UV $256 \mathrm{~nm}$.

Pada uji spesifitas daun anting-anting menghasilkan 8 noda, daun ekor kucing menghasilkan 7 noda, dan daun tehtehan menghasilkan 7 noda (Gambar 5). Selain itu, ketiga sampel memiliki noda dengan nilai $R f$ yang sama yaitu pada nilai $R f 0,39 ; 0,38 ; 0,38$; dan 0,39 . Namun, daun anting-anting memiliki noda penciri berwarna kuning kehijauan yang samar yaitu pada $R f 0,39$ sehingga noda ini yang membedakan dengan kedua sampel pembanding lainnya. Berdasarkan hasil uji spesifitas daun anting-anting tersebut dikatakan spesifik karena memiliki pola, jumlah, posisi, warna, dan intensitas noda yang dihasilkan berbeda dengan dua tanaman sampel pembanding lainnya. 


\subsection{Presisi dan Presisi Antara}

Uji presisi dan presisi antara dilakukan untuk mengetahui stabilitas analit dengan mengamati pengaruh lingkungan penyimpangan dengan perlakuan yang berbeda hari. Berdasarkan hasil pengembangan pada uji presisi diperoleh simpangan baku $R f(\Delta R f)$ senyawa berberin intrapelat pada pelat 1, pelat 2, dan pelat 3 berturut-turut adalah 0,0063 ; 0,0195; dan 0,0063 (Gambar 6 dan Tabel 1). Berdasarkan hasil tersebut dapat diperoleh simpangan baku $R f(\Delta R f)$ senyawa berberine antarpelat sebesar 0,0153 , sehingga presisi dapat diterima karena memenuhi syarat keberterimaan yaitu $\leq 0,02$.

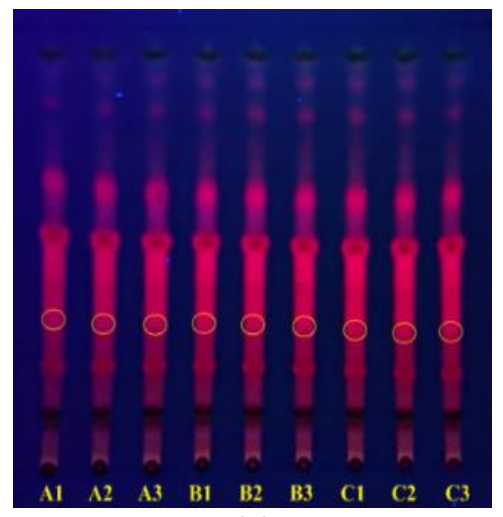

(a)

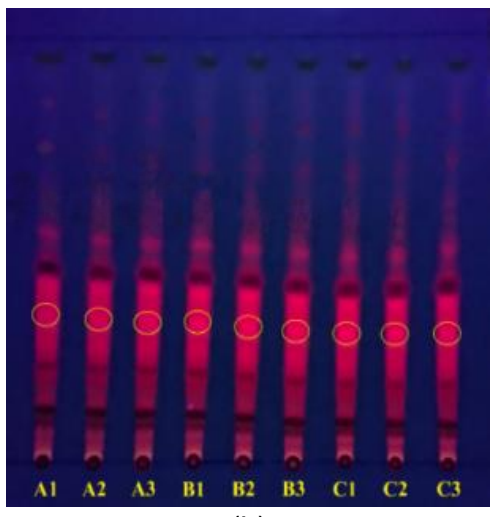

(b)

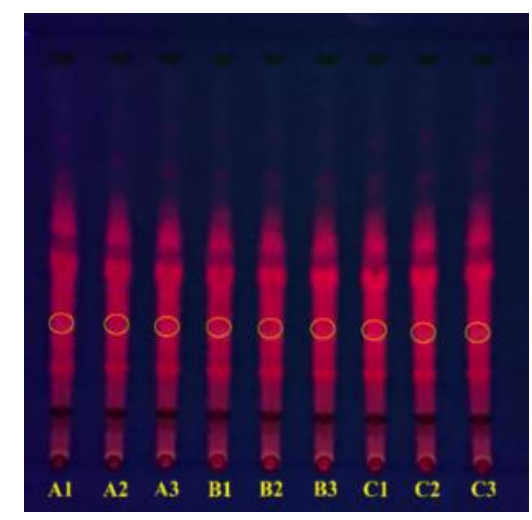

(c)

Gambar 6. Uji presisi daun anting-anting pada hari pertama, (a) pelat ke-1; (b) pelat ke-2; dan (c) pelat ke-3. A1 = Ekstrak Ulangan 1 (Lajur 1); A2 = Ekstrak Ulangan 1 (Lajur 2); A3 = Ekstrak Ulangan 1 (Lajur 3); B1 = Ekstrak Ulangan 2 (Lajur 1); B2 = Ekstrak Ulangan 2 (Lajur 2); B3 = Ekstrak Ulangan 2 (Lajur 3); C1 = Ekstrak Ulangan 3 (Lajur 1); C2 = Ekstrak Ulangan 3 (Lajur 2); C3 = Ekstrak Ulangan 3 (Lajur 3).

Tabel 1. Noda Penciri Senyawa Berberin Hasil Kromatografi Ekstrak Etil Asetat Daun Anting-Anting

\begin{tabular}{|c|c|c|c|c|c|c|}
\hline \multirow{2}{*}{ Ekstrak } & \multirow{2}{*}{ Lajur } & \multicolumn{3}{|c|}{ Rf Senyawa Berberin } & \multirow{2}{*}{ Hari ke-2 } & \multirow{2}{*}{ Hari ke-3 } \\
\hline & & Pelat 1 & Pelat 2 & Pelat 3 & & \\
\hline \multirow[t]{3}{*}{$A$} & $\mathrm{~A} 1$ & 0,325 & 0,313 & 0,300 & 0,350 & 0,338 \\
\hline & A2 & 0,313 & 0,313 & 0,300 & & \\
\hline & A3 & 0,313 & 0,300 & 0,300 & & \\
\hline \multirow[t]{3}{*}{$B$} & B1 & 0,313 & 0,300 & 0,300 & 0,363 & 0,313 \\
\hline & B2 & 0,313 & 0,300 & 0,300 & & \\
\hline & B3 & 0,313 & 0,288 & 0,300 & & \\
\hline \multirow[t]{3}{*}{ C } & C1 & 0,313 & 0,275 & 0,288 & 0,375 & 0,300 \\
\hline & C2 & 0,313 & 0,263 & 0,288 & & \\
\hline & C3 & 0,300 & 0,263 & 0,300 & & \\
\hline Rerata $R f$ intrapelat & & 0,313 & 0,290 & 0,296 & 0,363 & 0,317 \\
\hline Rerata $R f$ antarpelat & & 0,300 & & & 0,363 & 0,317 \\
\hline Rerata Rf semua pelat & & 0,307 & & & & \\
\hline SD $R f$ intrapelat & & 0,0063 & 0,0195 & 0,0063 & 0,0125 & 0,0191 \\
\hline $\mathrm{SD} R f$ antarpelat & & 0,0153 & & & 0,0125 & 0,0191 \\
\hline SD Rf semua pelat & & 0,0238 & & & & \\
\hline
\end{tabular}

Uji presisi antara dilakukan dengan mengembangkan 3 ekstrak yang telah dianalisis pada hari pertama, dan dilakukan kembali pada hari kedua dan ketiga pada satu pelat KLT 4x10 cm per harinya. Masing-masing ekstrak diaplikasikan pada 1 lajur pada pelat yang sama sehingga terdapat 3 lajur pada satu pelat KLT (Gambar 7). Hasil pengembangan pada hari pertama hingga hari ketiga sebagai uji presisi antara diperoleh simpangan baku $R f(\Delta R f)$ berturut-turut adalah 0,0063 ; 0,0125; dan 0,0191. Berdasarkan data tersebut dapat diperoleh simpangan baku $R f(\Delta R f)$ antarpelat sebesar 0,0238 , sehingga dapat disimpulkan bahwa uji presisi antara dapat diterima karena memenuhi syarat keberterimaan uji presisi antara yaitu $\leq 0,05$.

\subsection{Ketegaran}

Uji ketegaran merupakan uji yang digunakan untuk mengetahui kemampuan suatu metode dalam mempertahankan hasil yang tidak berbeda signifikan apabila dilakukan variasi parameter [23]. Pada penelitian ini dilakukan dua variasi parameter, yaitu jenis bejana pengembang dan jarak pengembangan. Jenis bejana pengembang yang dibandingkan 
adalah twin trough chamber dan flat bottom chamber. Sedangkan validasi metode ketegaran pada variasi jarak pengembangan dilakukan dengan membandingkan hasil kromatogram pada jarak pengembangan $8 \mathrm{~cm}$ dengan jarak pengembangan $7 \mathrm{~cm}$.

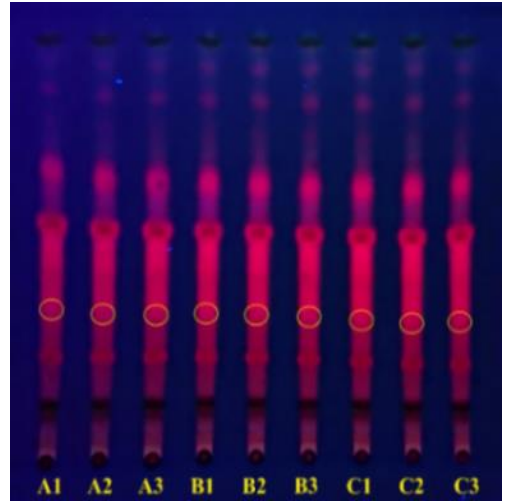

(a)

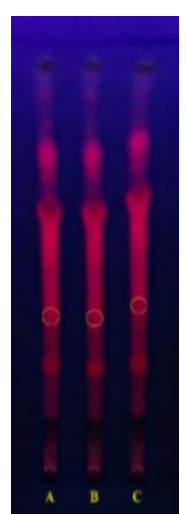

(b)

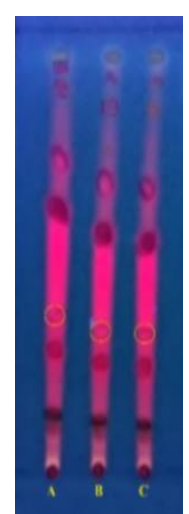

(c)

Gambar 7. Uji presisi antara daun anting-anting pada pelat (a) hari ke-1, (b) hari ke-2, dan (c) hari ke-3.

\subsubsection{Ketegaran terhadap Jenis Bejana Pengembang}

Uji ketegaran terhadap jenis bejana pengembang dilakukan dengan mengembangkan ekstrak anting-anting pada lajur 1 dan 2, serta standar berberin 100 ppm di lajur 3 menggunakan dua tipe bejana, yaitu twin trough chamber dan flat bottom chamber. Hasil kromatogram uji ketegaran terhadap jenis bejana menunjukkan bahwa kedua bejana menghasilkan pola sidik jari yang berbeda secara visual (Gambar 8). Hasil perhitungan rerata nilai Rf kedua pelat menunjukkan bahwa perbedaan jenis bejana pengembang tidak menimbulkan perbedaan nyata pada nilai $R f$ yang diduga berberin (Data tidak ditunjukkan). Berdasarkan nilai $R f$ yang diperoleh dapat diketahui bahwa simpangan baku nilai $R f(\Delta R f)$ antarpelat yaitu 0,037 (Data tidak ditunjukkan), sehingga uji ketegaran terhadap jarak pengembangan dapat diterima karena hasil simpangan baku $R f(\Delta R f) \leq 0,05$.
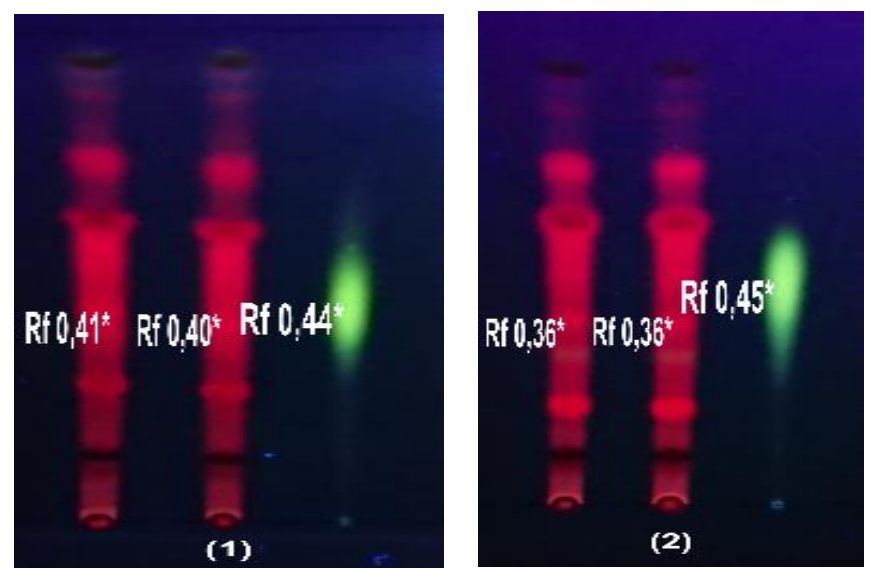

Gambar 8. Perbandingan kromatogram hasil pengembangan menggunakan jenis bejana (1) twin trough dan (2) flat bottom.
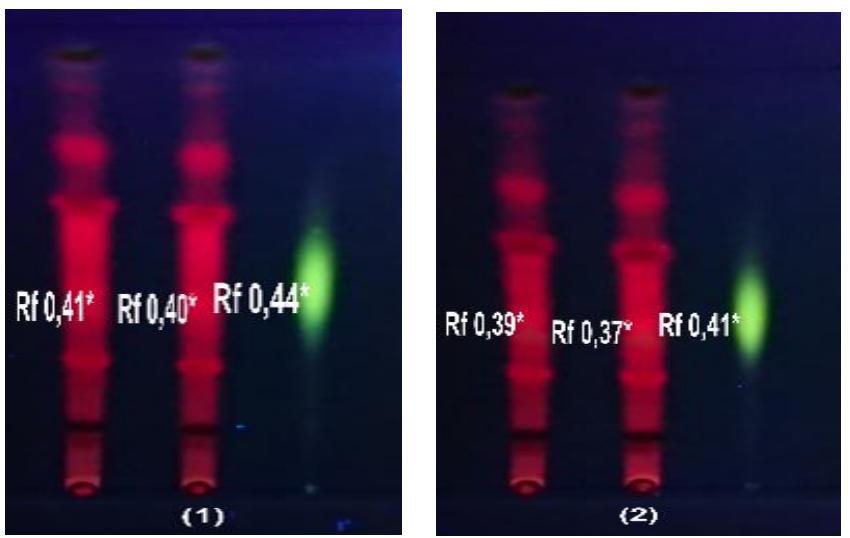

Gambar 9. Perbandingan hasil kromatogram dengan jarak pengembangan (1) $8 \mathrm{~cm}$ dan (2) $7 \mathrm{~cm}$. 


\subsubsection{Ketegaran terhadap Jarak Pengembangan}

Uji ketegaran terhadap jarak pengembangan dilakukan dengan mengembangkan ekstrak anting-anting pada lajur 1 dan 2, serta standar berberin 100 ppm pada lajur 3. Hasil kromatogram uji ketegaran terhadap jarak pengembangan secara visual menunjukkan bahwa perbedaan jarak pengembangan tidak memengaruhi pola sidik jari yang dihasilkan (Gambar 9). Berdasarkan hasil kromatogram penurunan jarak pengembangan dari $8 \mathrm{~cm} \mathrm{ke} 7 \mathrm{~cm}$, diperoleh simpangan baku nilai $R f$ $(\Delta R f)$ antarpelat sebesar 0,025 (data tidak ditunjukkan) dan telah memenuhi syarat keberterimaan dengan nilai simpangan baku $R f(\Delta R f) \leq 0,05$. Hal ini mengindikasikan bahwa uji ketegaran jarak pengembangan daun anting-anting dapat dilakukan pada kedua variasi jarak tersebut.

\section{Kesimpulan}

Berdasarkan hasil penelitian yang telah dilakukan, maka dapat disimpulkan bahwa uji validasi metode dapat diterima sesuai kriteria kecuali uji stabilitas analit selama kromatografi. Profil sidik jari daun anting-anting terhadap daun ekor kucing menghasilkan 7 noda dan terhadap daun teh-tehan menghasilkan 7 noda. Selain itu, pada kromatogram daun anting-anting terdapat noda dengan warna kuning kehijauan yang sedikit samar pada $R f$ 0,39 yang tidak dimiliki oleh dua tanaman pembanding tersebut. Berdasarkan hasil validasi dapat disimpulkan metode ini dapat digunakan dalam kendali mutu tanaman anting-anting.

\section{Daftar Pustaka}

[1] M. Untoro, E. Fachriyah, \& D. Kusrini, "Isolasi dan Identifikasi Senyawa Golongan Alkaloid dari Rimpang Lengkuas Merah (Alpinia purpurata)," Jurnal Kimia Sains dan Aplikasi, vol. 19, no. 2, pp. 58-62, 2016.

[2] F. T. Rahmah, "Uji Toksisitas Anting-Anting (Acalypha indica, L.) Hasil Ekstraksi Ultrasonik dengan Variasi Pelarut dan Lama Ekstraksi," Skripsi, Universitas Islam Negeri Maulana Malik Ibrahim, Malang, 2018.

[3] R. Ocktarini, "Pengaruh Ekstrak Herba Anting-Anting (Acalypha australis, L.) terhadap Kadar Glukosa Darah Mencit Balb/C Induksi Streptozotocin," Skripsi, Universitas Sebelas Maret, Surakarta, 2010.

[4] A. Ameilia, "Khasiat Anting-Anting (Acalypha indica L)," Majalah Farmasetika, vol. 3, no. 1, pp. 7-11, 2018.

[5] I. Batubara, W. T. Wahyuni, \& I. Firdaus, "Utilization of Anting-Anting (Acalypha indica) Leaves as Antibacterial," in IOP Conference Series: Earth and Environmental Science, vol. 31, no. 012038, 2016.

[6] I. Pratiwi, "Uji Antibakteri Ekstrak Kasar Daun Acalypha indica Linn. terhadap Bakteri Salmonella choleraesuis dan Salmonella typhimurium," Skripsi, Universitas Sebelas Maret, Surakarta, 2009.

[7] V. T. Narwade, A. A. Waghmare, \& A. L. Vaidya, "Detection of Flavonoids from Acalypha indica L.," Journal of Ecobiotechnology, vol. 3, no. 11, pp. 5-7, 2011.

[8] M. Wink, "Ecological Roles of Alkaloids," in Modern Alkaloids: Structure, Isolation, Synthesis and Biology, E. Fattorusso \& O. Taglialatela-Scafati, Ed. Weinheim: Wiley-VCH Verlag GmbH \& Co. KGaA, 2007.

[9] B. N. Aer, A. C. Wullur, \& G. Citraningtyas, "Uji Efek Ekstrak Etanol Kulit Terung Ungu (Solanum melongena L.) terhadap Kadar Gula Darah pada Tikus Putih Jantan Galur Wistar (Rattus norvegicus)," PHARMACON Jurnal IImiah Farmasi, vol. 2, no. 4, pp. 135-141, 2013.

[10] E. K. Hayati, A. Jannah, \& R. Ningsih, "Identifikasi Senyawa dan Aktivitas Antimalaria in Vivo Ekstrak Etil Asetat Anting-Anting (Acalypha indica L.)," Molekul, vol. 7, no. 1, pp. 20-32, 2012.

[11] S. Dalimartha, Atlas Tumbuhan Obat Indonesia Jilid 5. Jakarta: Pustaka Bunda, 2008.

[12] M. Masih, T. Banerjee, B. Banerjee, \& A. Pal, "Antidiabetic Activity of Acalypha indica Linn. on Normal and Alloxan Induced Diabetic Rats," International Journal of Pharmacy and Pharmaceutical Sciences, vol. 3, no. 3, pp. 51-54, 2011.

[13] H. S. Kirom \& Z. M. Ramadhania, "Review Artikel: Aktivitas Biologis Tanaman Kucing-Kucingan (Acalypha indica L.)," Farmaka, vol. 15, no. 3, pp. 162-168, 2017.

[14] M. Rafi, R. Heryanto, \& D. A. Septaningsih, ATLAS Kromatografi Lapis Tipis Tumbuhan Obat Indonesia Volume I. Bogor: IPB Press, 2017.

[15] X,-M. Liang, Y. Jin, Y.-P. Wang, G.-W. Jin, Q.. Fu, \& Y.-S. Xiao, "Qualitative and Quantitative Analysis in Quality Control of Traditional Chinese Medicines," Journal of Chromatography A, vol. 1216, no. 11, pp. 2033-2044, 2009.

[16] L. Zhao, C. Huang, Z. Shan, B. Xiang, \& L. Mei, "Fingerprint Analysis of Psoralea corylifolia L. by HPLC and LC-MS," Journal of Chromatography B, Analytical Technologies in the Biomedical and Life Sciences, vol. 821, no. 1, pp. 6774, 2005.

[17] N. A. Andhika, "Sidik Jari Kromatografi Lapis Tipis dari Daun Tiga Jenis Jambu Biji," Skripsi, Institut Pertanian Bogor, Bogor, 2011.

[18] S. R. Yolanda, "Pengembangan Metode Analisis Sidik Jari Sidaguri (Sida rhombifolia L.) Menggunakan Kromatografi Lapis Tipis," Skripsi, Institut Pertanian Bogor, Bogor, 2017. 
[19] Y. Eleanore, "Analisis Fitokimia dan Aktivitas Antioksidan Ekstrak Daun Sengon (Paraserianthes falcataria (L) Nielsen) Menggunakan Metode DPPH," Skripsi, Institut Pertanian Bogor, Bogor, 2013.

[20] E. Reich, \& A. Schibli, "Validation of High-Performance Thin-Layer Chromatographic Methods for the Identification of Botanicals in a cGMP Environment," Journal of AOAC International, vol. 91, no. 1, pp. 13-20, 2008.

[21] E. W. Safitri, "Optimasi Variasi Pelarut dan Variasi Lama Ekstraksi Ultrasonik Senyawa Aktif Alkaloid pada AntingAnting (Acalypha indica L.) serta Identifikasi Menggunakan Kromatografi Lapis Tipis," Skripsi, Universitas Islam Negeri Maulana Malik Ibrahim, Malang, 2018.

[22] Y. Qoriati, "Optimasi Ekstraksi Ultrasonik dengan Variasi Pelarut dan Lama Ekstraksi terhadap Kadar Alkaloid Total pada Anting-anting (Acalypha indica L.) Menggunakan Spektrofotometer UV-Vis," Skripsi, Universitas Islam Negeri Maulana Malik Ibrahim, Malang, 2018.

[23] A. U. Fatahillah, "Analisis Sidik Jari Kromatografi Lapis Tipis Tanaman Pegagan (Centella asiatica)," Skripsi, Institut Pertanian Bogor, Bogor, 2016. 